\title{
A Study about Urban Design Schemes: Walled City of Nicosia
}

\author{
By Mine Kuset Bolkaner ${ }^{1}$, Buket Asilsoy ${ }^{1}$, Semra Sema Uzunoğlu ${ }^{2}$
}

\begin{abstract}
Historical neighbourhoods are among the most significant indicators of the cities; as they involve history, culture, architecture and social life. It is very important to protect and ensure sustainability of these places. This goal needs to be achieved without damaging the urban identity via protecting the historic entities. Additionally the restoration and re-use works need to take place under the supervision and cooperation of related government bodies and civil society organisations. Nicosia with its Walled City is a historical environment with a rich architectural and cultural heritage that is currently the focal point of conservation and rehabilitation activities as a circle of urban design implementations. Within this framework in this study, the aim is to evaluate perception and views of the users about urban design implementations involving rehabilitation and conservation activities via survey. Based on the results, the users seemed satisfied with the outcomes of the rehabilitation and re-use of the buildings. However the participants also highlighted the existence of car parking problems, inadequate infrastructure and urban furniture and environmental pollution. Additionally the users do not prefer the areas that have not been renovated and the regions with low sociocultural characteristics.
\end{abstract}

Keywords: Historical environment; urban design; user perception; Nicosia W alled City

\section{Introduction}

Especially after the Industrial Revolution, cities in parallel with rapid population growth are changing rapidly. Throughout this rapid change, historical environments involving rich characteristics are under pressure of deterioration. As such, many historic quarters are in a danger of losing their traditional character if relevant measures are not put in place to ensure the continuity of this character (Doratli et al., 2004).

Historical environments are cultural assets that make an important connection between the past and present and have historical, documentary, artistic, architectural and functional values. In other words, historical urban areas are the memory of a city, and the overall landscape they constitute displays the typical scene of a city in a certain historical period (Wang, 2012).

Additionally, historical urban environments are significant items of the city in providing urban identity by supporting especially cultural and social dimensions of sustainability (Bolkaner et al., 2019). Therefore, in addition to restoration, repair and conservation works, also concepts like rehabilitation and adaptive reuse have all became widespread and gained importance in the meantime. In other words, in order to be transferred to future generations, these areas, which are considered as living traditional cultures and cultural landscapes, must be maintained and protected with sustainable uses. 
Cyprus as an island of the Mediterranean basin is distinguished with her unique traditional architecture (Dincyurek \& Turker, 2007). Nicosia with its Walled City as the capital of the island in particular, is a historical environment with a rich architectural and cultural heritage; it is divided into two as a north and south and the Green Line is passing through it. Walled City, as a footprint of the historical urban texture of Nicosia, is like an open-air museum; it displays traces of the past periods of the island with many entities of different cultures throughout the history of the city (Turkan \& Özburak, 2018).

However Nicosia Old City, as one of the oldest centres, has taken its share from the decline of changing values, political and socio economic factors, population dynamics etc. Therefore, Nicosia Walled City with a rich historical background dating back to ancient times and involving the marks of Roman Period, Byzantine Period, Middle Age, Renaissance Period and Ottoman Period, British Administration Period etc. has been a focal point of urban design planning and implementations in recent years.

These conservation works in the northern part of the city of Nicosia are provided by the support of international organizations like UNDP, EU and Turkish Republic and the implementations are fulfilled by the Municipality, Ancient Antiquities Department and the City Planning Department. In addition, restoration and re-functionalization by investments, universities or non-governmental organizations is increasing rapidly in certain regions.

At this point it can be argued that contrary to the ordinary physical environments, the historical environments, with the landscape planning and urban design activities, enable us to live in a more liveable and qualified environment. But one of the important factors for the accomplishment of these urban design activities for the sustainability of historical environments is to know the opinions and preferences of the users while planning these unique environments and to develop plans according to their requests and suggestions. Otherwise these attempts would be deficient.

In this context, this study deals with the urban design approaches in historical environments. It has chosen northern Nicosia as research context. Hence Nicosia as the capital city, has been the focal point of many urban design projects.

Within this scope, the aim of this study was to investigate the perception and views of the users about urban design implementations in Nicosia Old City through a survey as field study. For this purpose, first, a theoretical framework was developed and then the methodology including the findings of the survey was displayed. Finally, conclusion and discussion were derived.

\section{Literature Review}

\subsection{Historical Environment and Urban Design}

Cities are places that have been constantly changing from the first day they were formed to the present day. After the Industrial Revolution, cites have begun to grow rapidly in such a way bringing serious problems (Kamruzzaman, Deilami, \& Yigitcanlar, 2018; Marquez-Ballesteros et al., 2019). In this process of change, the political, physical, cultural, economic and social structures of the cities are also transforming. Historical environments are the cultural assets of the cities and establish an important connection between the past and the present. These cultural assets help us learn and understand our 
past, giving us insights into the past. The events witnessed and experienced in historical environments directly or indirectly affect the relationships of people in the city with each other and consequently affect the urban design and usage of urban space.

The remaining settlements and ruins belonging to past periods constitute the historical environment. Many important values related to the life style, social, cultural and economic structure, aesthetic and architectural properties of the past periods are hidden within the historical environments. Historical environments are the environments that increase the sense of unity and solidarity among individuals, thus affecting the social relations between people in a positive way (Ahunbay, 1996). In the study of the European Council for Cultural Cooperation as 'Inventory of European Cultural Heritage', historical environment is defined as follows: 'Natural or individual-formed, integrity and artistic, aesthetic, historical, ethnographic, scientific, literary or legendary features that must be protected and evaluated. Historical environments can be places where significant events take place, as well as parts of the city that convey messages about the cultural, socio-economic structure and understanding of the art of a certain period (Çelik, 2004).

The city is an element of the individual's spiritual and physical culture and is in fact the most important expression of the culture. Today, urban spaces created are the subject of urban design discipline. Urban design is a method of creating a built environment to realize the desires of human beings and to show their values (Moughtin, 2003). The concept of urban design was first born in North American countries, where urbanization was rapid and massive. Urban design emphasizes the necessity of the quality of life and has a target to create places where the user would like to prefer (Karaman, 2008).

According to Hoşkara (2008), another theoretical perspective within the scope of urban design is related to the historical urban quarters that constitute the most important part of the identities of our cities reflecting the past. The natural and cultural values of the city are physical elements that give identity to the city within history as an image of the city. In other words, among the most dominant and effective elements that give character to our cities and in which the citizens can feel themselves in harmony with the city are the historical circles and historical urban quarters giving city the fourth dimension. From the past civilizations to the present day, historical environments formed by physical traces appear in many different ways.

There should be a delicate relationship between urban design and the built environment. For example, economic growth should be promoted, historical continuity ensured and individuals' consciousness should be enhanced. The task of urban design is to create qualified, liveable and diverse spaces for all residents and visitors of the city (Davies, 2000).

\subsection{Historic Environmental Protection and Renovation}

Historical environmental conservation studies, restoration of historical buildings and revitalization studies were first applied in developed European countries. These studies came to the agenda within the reconstruction and repair of the cities which were destroyed as a result of I. and II. World wars. The rapid urbanization experienced with the Industrial Revolution also increased the importance of historical environmental protection activities in the meantime. Especially due to the migrations from rural areas to 
urban centres, these environments grew rapidly and uncontrolled, the population increased and the traffic density increased accordingly. These densities have consequently caused negative effects on historical environments.

In the dictionary of architecture, conservation is defined as "taking the necessary measures to ensure that historical cities or buildings can survive without losing their historical and artistic value" (Hasol, 1998). According to Çelik and Yazgan (2007), the purpose of protecting and renovating historical environments is ensuring that cultural, historical and architectural values are passed on to the next generations. In addition, the opportunities provided by contemporary life must be considered for the revival of these environments while preserving their original identity in a healthier manner.

In other words in historical environments, it is necessary to preserve the quality of the environment while revitalizing and preserving. In addition, it is imperative to achieve a balance with economic development. The basis of the revitalization in historical environments is the strategic planning of the social, economic and environmental components of the city within the short and long term. The purpose of this strategic planning is to protect the existing values in historical environments, to develop the necessary aspects of these environments and to eliminate the negative effects on these environments and to improve the environment (Doratli et al., 2004).

Sustainability of historical environments depends on revitalization and renewal. In order to achieve integrated conservation, sustainability in historical environments and revitalization strategies should be implemented at the urban scale. For urban revitalization to be sustainable, physical revitalization should be implemented in the short term and economic and social revitalization should be implemented in the long term. The creation of sustainable environments in historical environments depends on the improvements in economic, physical and especially social life. Vehbi and Hoşkara (2009) have therefore created a model for sustainability in historical environments. In this model, three topics are considered for the sustainability of historical environments. These are sustainable physical revitalization, sustainable economic revitalization and sustainable social revitalization. See Figure 1 and 2 displaying Piazza del Campo Square in Siena, Italy as a historical urban environment.

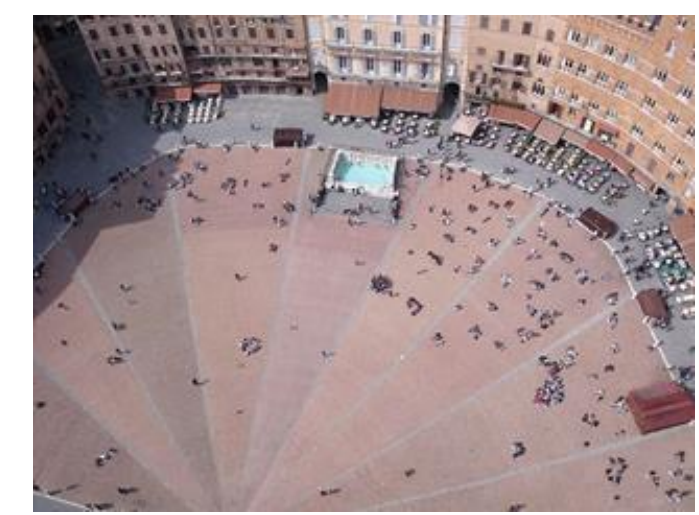

Figure 1: Historic Piazza del Campo Square (Project for Public Spaces, 2016) 


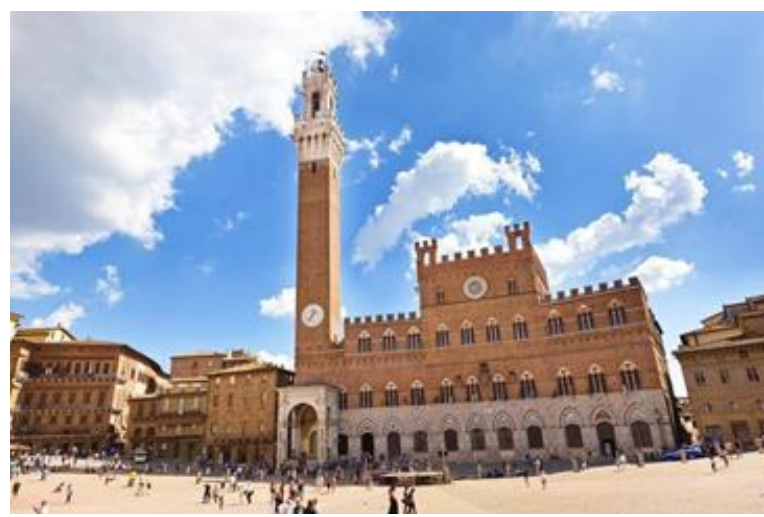

Figure 2: Piazza del Campo Square in Italy (Hürriyet, 2017)

Historical environments also have the ability to boost formation of urban identity. Identity can be defined as the separation of an object or an object from others in terms of individuality, specificity and technique. The identity of the city helps to differentiate and differentiate a city from other cities and it contains the original elements and qualities of the city (Lynch, 1960).

According to Tunçer (1997), the main elements constituting the characteristics of urban identity can be listed as follows; The climatic conditions of the region, the traditional architecture developed in harmony with these climatic conditions, the building materials used, building techniques, the characteristics of the regions and sub-regions in which the region interacts with the urban texture and space, the factors affecting the shaping of the social structure and economic structure. These factors also shape cities and lead to the formation of urban identity including social identity. On the other hand, ethnographic qualities such as traditional handicrafts and folklore can occur in a historical process in social and physical environments. As such, historical environments are one of the basic elements that achieve identity to the settlements in which they are located. These environments also carry important values as the image elements of the city.

\subsection{Urban conservation and renovation}

The concept of conservation began to develop in the second half of the 19th century and did not include the preservation of individual characteristics, but the implications of deterioration in areas where historical continuity was reflected and the accumulation of cultural heritage. Therefore, protection is an action taken to prevent corruption (Feilden 1982).

Urban conservation can be applied to all urban centres of different scales, a part or a small rural accumulation. The implementation of an urban conservation should control the new development in the historical fabric and include a characteristic according to the socio-economic situation of the society (Yazgan ve Erdoğan, 1992).

Urban regeneration includes revitalization of urban areas, rehabilitation of historical sites, improvement of living conditions in residential areas and redevelopment of public spaces. Urban renewal, according to Robert and Skyes (2000), is an action aimed at solving urban problems and making long-term improvements that are appropriate to the 
economic, physical, social and environmental characteristics of a changing area. The objectives of urban renewal are as follows: To ensure the clear and measurable objectives of the urban renewal process and to establish them in accordance with sustainable development objectives, to analyse local conditions, to ensure the efficient use of natural, economic and human resources, to ensure the participation and cooperation of users, to improve the physical condition of buildings, social and economic structure and environmental conditions (Alpopi ve Manole, 2013). At this point we can argue that; urban renewal and conservation are the elements that ensure the continuity of the historical urban patterns which have changed greatly. Conservation is generally the preservation of the properties of immovable cultural and natural assets within legal means (Çavdar ve Sayan, 2003).

Practices for the protection of historical environments, which started to raise funds for monuments that are important in Europe, especially in the late 19th century, were first mentioned at the Athens Conference (organized by the International Museums Organization) in 1931 for the first time. In the context of improving the aesthetic value of historical monuments, it is recommended that the identity, appearance and especially the surrounding environment of the settlements be respected within construction activities. In addition, the formation of landscapes, which are beautiful in terms of some building groups and features, should be preserved.

Urban and rural conservation efforts in Europe gained momentum after 1945. Such that, as individuals were mostly aware of the losses of the historical environments whose character was also disrupted by modern structuring and industrialization, public began to seek a solution for the cities which was destroyed during World War II. In May 1964, the second International Congress of Architects and Technicians of Historic Monuments convened in Venice. Including urban and rural settlements for the definition of the concept of 'historical monument' in the first article of the Venice Charter within the framework of the decisions taken at the meeting, has been an important step for the protection of historical environments. As a result, many countries acknowledged the Venice Charter and have established the legal framework for protection of historical environments.

\subsection{Examples of Sustainable Revitalization in Historical Environments}

Sustainable historical environment is the environment where the built and natural environment, natural and cultural assets, economic opportunities and social values are all protected in a holistic perspective. In this case, sustainable historical environments are urban areas with different uses and activities and various social income groups. These urban areas achieve suitable housing, living spaces and qualified social/public spaces. In these environments the historical values are not consumed and intensive public participation are delivered (Oktay and Hoşkara, 2006).

Viva o Center in Brazil is one of the most prominent revitalization projects especially in terms of user participation. One another significant example of the revitalization projects implemented in historical environments is the award-winning Ciutat Vella in Spain, and one another is Manchester City Center Plan in the United Kingdom, which has undergone a major transformation after an explosion. See Figure 3. 


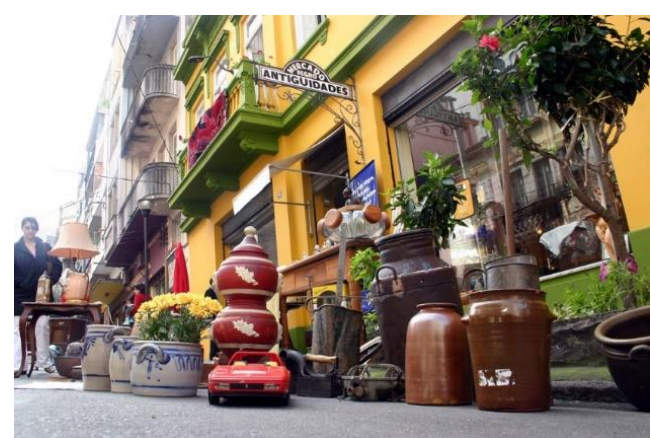

Figure 3: Antique Fair area (Caminho dos Antiquarios) in the city center, improved under the Viva o Centro program (Governo do Brasil, 2010)

\section{Relationship between Urban Design and Historical Environment Protection}

Today preserving the historical environment has a universal status. The preservation of the historic environment and historical structure basically consists of a contemporary cultural intention. This desire develops in parallel with the modernization of the culture of society. The biggest problem faced while preserving the historical environment is the contemporary environment and contemporary comfort created by industrialization. The desire and intention to preserve the historical environment is shown both as conservatism and an obstacle to innovation and progress. However, there is no contradiction here. As it is encountered in many areas, the objection is not for the industry but for the fact that it is one-dimensional. This industrial activity prevents the healthy development of the environment as a linear interpretation. As it involves the consumption pressure that forgets human dimensions, it becomes a slave to a blind production system which has been cut off from organic life and personal life (Kuban, 2000).

\subsection{The Impact of Urban Users on Historical Environments}

Users living in traditional urban tissues and spaces play an active role in whether these tissues can be preserved or not. However, they are generally socio-economic and socio-culturally alien to their environment. When the relationship between the users and the environment they live in is considered within the framework of the socio-cultural characteristics of the users, it is seen that they have problems about perception, understanding and evaluation about the structured environment. Depending on the socio-economic structure of the users, various problems such as the protection, management and maintenance of the physical structure of the urban tissues and spaces constituting the environment are experienced (Uğur ve Giritlioğlu, 2006).

People living in the historical environments need to have the perception and consciousness to save the existing environment they are living in to future generations without damaging them. Users who migrate from rural areas to the historical parts of the city use these buildings unconsciously because they do not know the architectural values of the buildings they live in. However in local settlements that host their own local people, individuals are connected to their homes and surrounding environments by family ties and memories. Therefore, the idea of protecting their environment would be more developed in these individuals. On the contrary, historical residences may only be a 
cheap shelter for these people. As a result of this, historical buildings are used badly, the wooden coverings of the abandoned buildings are dismantled in order to be burned, the rooms with wall decoration are unconsciously painted and the ceilings are damaged. In order to prevent such damages, it is necessary to provide the necessary control against the deliberate destruction and increase the economic and educational level of the users of these structures (Ahunbay, 1996).

According to Vehbi and Hoşkara (2009), for increasing physical and environmental sustainability in historical areas, it is needed to ensure the use of existing buildings, to improve the built environment and to protect the historical buildings while doing these, to reconstruct abandoned open spaces and to provide green spaces in historical urban areas, environmental revitalization. Therefore, local people living in these historical areas should feel themselves as part of these areas and participate in the physical improvements made in these areas. With this awareness and concern of the users, these areas would become more preferable.

\subsection{Nicosia Walled City as Study Area}

The city of Nicosia, located in the geometric centre of the country, is located at the intersection of the main land transport network connecting Famagusta, Kyrenia and Güzelyurt. Nicosia, the most populous and most important cultural city of Cyprus, is the centre of industry, trade and transportation.

Nicosia is the only divided capital in the world. The city is divided into two parts with the Green Line as northern and southern Nicosia. The city of Nicosia remains the centre of the country in terms of business, management, education, culture and various other activities due to its proximity to the sea and air gates of the country. Nicosia Walled City is the heart of the city and the most valuable part of the capital's identity due to its international architectural and historical heritage. See Figure 4.
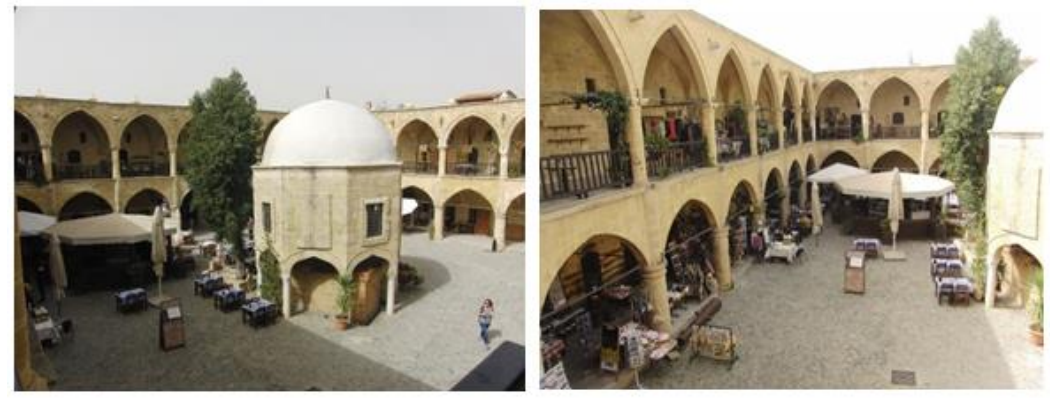

Figure 4: Great Inn, Nicosia Old City (Bolkaner, 2018)

Cyprus Island's capital Nicosia is an old city located in the central part of the Mesarya Plain, having the Pedios River within which the Turks call Kanlidere (Gürkan, 1996). Cyprus Island has been under the control of many empires and kingdoms for many years due to its geographical position. These empires and kingdoms have had important effects especially on the physical change of the city of Nicosia in the center of the island. According to written sources of Cyprus, it has a history dating back to 7000-3000 BC (Altan, 2016). See Figure 5 and 6. 


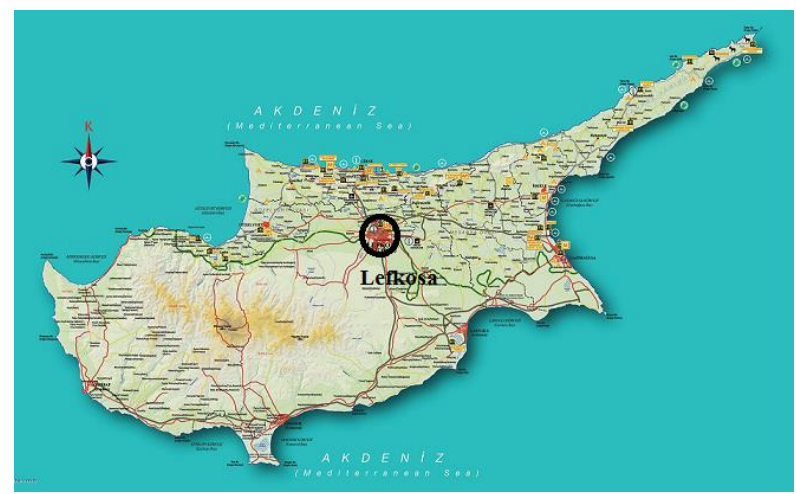

Figure 5: Map of Cyprus Island (kibris.com.tr, 2018)

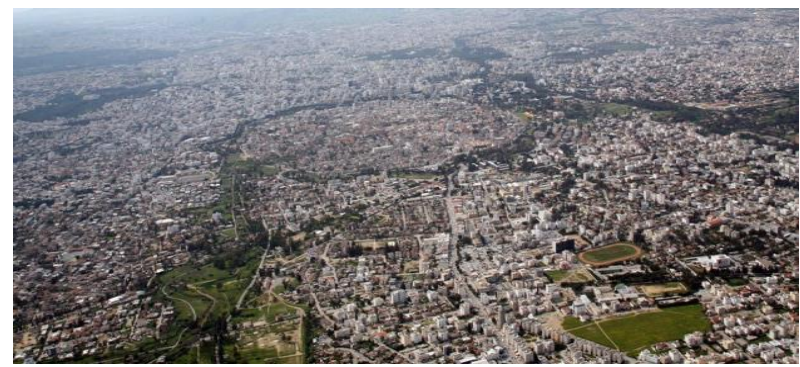

Figure 6: Bird's-eye view of Nicosia (T.R.N.C City Planning Department, 2018)

\section{Methodology}

\subsection{Sample, Measures and Research Design}

The population size of the participants were 120 individuals selected randomly for the survey. 40 people were selected within existing Walled City regions, 40 participants were users and tourists who came to the region and in addition 40 participants were selected from the other parts of Nicosia; 20 respondents were interviewed in total.

The questionnaire prepared in order to collect the data consists of three parts. In the first part having seven items, there were questions about the demographic characteristics of the individuals participating in the survey. In the second part with six items, questions were asked about the users' frequency and reasons to visit to Nicosia Wall. In the third section, there were 16 questions examining the opinions of the users about urban design studies carried out in the Nicosia Walled City region, rehabilitation city. In this section, 5 -point Likert scale (strongly agree $=5$, agree $=4$, unsure $=3$, disagree $=2$, strongly disagree $=1$ ) was used.

The questionnaire was applied between 02.03.2018-07.03.2018 by using face to face interview technique. Before the questions were conveyed to the participants, the participants were informed about the aims of the research and it was stated that the obtained data would be used only in the scientific study. In this study, findings of the first and third section will be evaluated excluding second section as follows. 


\subsection{Findings}

\subsubsection{Findings of participants' socio-demographic profile}

$45.0 \%$ of the individuals included in the study were female and $55.0 \%$ were male. It was seen that $41.67 \%$ of the individuals included in the study were between 1834 years, $26.67 \%$ were between $35-44$ years and $31.67 \%$ were in the age group 45 years and over.

When the distribution of participants according to their educational background is examined, it is seen that $10.0 \%$ of them are primary school graduates, $3.33 \%$ are high school graduates, $40.83 \%$ are undergraduate and $15.83 \%$ are graduate graduates. $41.67 \%$ of the individuals included in the study were private sector employees, $10.83 \%$ were civil servants and $30.83 \%$ were self-employed. See Table 1 .

Table 1: Distribution of participants by demographic characteristics $(\mathrm{n}=120)$

Features

Number (n)

Percentage $(\%)$

Gender

Female

$\begin{array}{ll}54 & 45,00 \\ 66 & 55,00\end{array}$

Male

55,00

Age Group

Between 18-34 years 50

Between 35-44 years 32

41,67

45 years and older

26,67

Nationality

TRNC

38

31,67

TC

$95 \quad 79,17$

Place of residence

TRNC

25

20,83

Other

102

85,00

TRNC survival time $(\mathrm{n}=102)$

10 years and under

11 - 20 years 8

$\mathbf{2 1}$ - $\mathbf{3 0}$ years 21

15,00

$30+$

63

$\begin{array}{ll}10 & 9,80 \\ 8 & 7,84\end{array}$

$21 \quad 20,59$

Education

Primary education 12

61,76

Primary education

10,00

Undergraduate

33,33

Graduate

40,83

Job

Student

40

15,83

Officer

6,67

Private sector

10,83

Self-employment

41,67

Retired

30,83

Unemployed

$\begin{array}{cc}8 & 6,67 \\ 13 & 10,83 \\ 50 & 41,67 \\ 37 & 30,83 \\ 10 & 8,33 \\ 2 & 1,67\end{array}$

\subsubsection{Findings of third section of the survey}

Table 2 shows the distribution of the views of the individuals on the urban design implementations of Nicosia Walled City region. 
Table 2: Distribution of participants' views on the Nicosia Walled City $(n=120)$

\begin{tabular}{|c|c|c|c|c|c|c|}
\hline & \multicolumn{2}{|c|}{ Agree } & \multicolumn{2}{|c|}{ Unsure } & \multicolumn{2}{|c|}{ Disagree } \\
\hline & $\mathbf{n}$ & $\%$ & $\mathbf{n}$ & $\%$ & $\mathbf{n}$ & $\%$ \\
\hline $\begin{array}{l}\text { 1. I find the rehabilitation and restoration works done in } \\
\text { the region sufficient. }\end{array}$ & 45 & 37,50 & 18 & 15,00 & 57 & 47,50 \\
\hline $\begin{array}{l}\text { 2. I think that the pedestrianization activities carried out } \\
\text { in certain regions in the Walled City region contributed } \\
\text { to the Walled city economy. }\end{array}$ & 62 & 51,67 & 30 & 25,00 & 28 & 23,33 \\
\hline $\begin{array}{l}\text { nd re-functionalization in the } \\
\text { gional economy. }\end{array}$ & 95 & 79,17 & 9 & 7,50 & 16 & 13,33 \\
\hline hat there is a lot of environmental pollution in & 86 & 71,67 & 13 & 10,83 & 21 & 17,50 \\
\hline $\begin{array}{l}\text { 5. As one of the important problems in the region, I find } \\
\text { the lack of parking lots. }\end{array}$ & 102 & 85,00 & 8 & 6,67 & 10 & 8,33 \\
\hline $\begin{array}{l}\text { 6. I find inadequate pedestrian roads and green areas in } \\
\text { the region. }\end{array}$ & 95 & 79,17 & 6 & 5,00 & 19 & 15,83 \\
\hline e signage and orientation signs in the region & 53 & 44,17 & 17 & 14,17 & 50 & 41,67 \\
\hline 8. I find the & 32 & 26,67 & 23 & 19,17 & 65 & 4,17 \\
\hline $\begin{array}{l}\text { 9. I find the lighting elements } \\
\text { sufficient. }\end{array}$ & 25 & 33 & 26 & 21,67 & 69 & 57,50 \\
\hline $\begin{array}{l}\text { 10. I a } \\
\text { the re }\end{array}$ & 30 & 25,00 & 29 & 24,17 & 61 & 50,83 \\
\hline 11. Satisfied with the traffic & 22 & 18,33 & 16 & 13,33 & 82 & 0,0 \\
\hline $\begin{array}{l}\text { 12. I think that the façade and floor coverings used in } \\
\text { the renovation works in the region are suitable for the } \\
\text { historical environment of the region. }\end{array}$ & 53 & 44,17 & 25 & 20,83 & 42 & 35,00 \\
\hline $\begin{array}{l}\text { 13. I find public transportation necessary in the city of } \\
\text { Nicosia. }\end{array}$ & 71 & 59,17 & 18 & 15,00 & 31 & 25,83 \\
\hline $\begin{array}{l}\text { 14. I find it appropriate to use the re-functionalized } \\
\text { structures in the region by universities, artists or non- } \\
\text { governmental organizations. }\end{array}$ & 96 & 80,00 & 11 & 9,17 & 13 & 10,83 \\
\hline $\begin{array}{l}\text { 15. I find it convenient to use the re-functionalized } \\
\text { structures in the region by businesses with restaurants, } \\
\text { bars, cafes and the like. }\end{array}$ & 103 & 85,83 & 8 & 6,67 & 9 & 7,50 \\
\hline $\begin{array}{l}\text { 16. I t } \\
\text { buildi }\end{array}$ & 113 & 94,17 & 3 & 2,50 & 4 & 3,33 \\
\hline
\end{tabular}

Table 3 presents the results of the chi-square analysis in order to compare the views of the participants regarding the age groups. It is seen that the rate of users between 18-34 years of age agreeing with this proposition is higher than the users of other age groups. On the other hand, the difference between the responses of the users to the other propositions according to age groups was not statistically significant ( $p>0.05$ ). Regardless of age groups, participants' responses to other propositions were similar. See Table 3. 
Table 3: Comparison of participants' views on the Nicosia Walled City region by age groups

\begin{tabular}{|c|c|c|c|c|c|c|c|c|c|}
\hline & & \multicolumn{2}{|c|}{$18-34$ years } & \multicolumn{2}{|c|}{$35-44$ years } & \multicolumn{2}{|c|}{45 years and older } & \multirow{2}{*}{$\mathbf{X}^{2}$} & \multirow{2}{*}{$\mathbf{P}$} \\
\hline & & $\mathrm{n}$ & $\%$ & $\mathrm{n}$ & $\%$ & n & $\%$ & & \\
\hline \multirow{2}{*}{ Item 1} & Agree & 17 & 42,50 & 18 & 64,29 & 22 & 64,71 & \multirow{2}{*}{4,781} & \multirow{2}{*}{0,092} \\
\hline & Not agree & 23 & 57,50 & 10 & 35,71 & 12 & 35,29 & & \\
\hline \multirow{2}{*}{ Item 2} & Agree & 7 & 17,50 & 7 & 36,84 & 14 & 45,16 & \multirow{2}{*}{6,604} & \multirow{2}{*}{$0,037^{*}$} \\
\hline & Not agree & 33 & 82,50 & 12 & 63,16 & 17 & 54,84 & & \\
\hline \multirow{2}{*}{ Item 3} & Agree & 6 & 13,04 & 2 & 6,90 & 8 & 22,22 & \multirow{2}{*}{3,178} & \multirow{2}{*}{0,204} \\
\hline & Not agree & 40 & 86,96 & 27 & 93,10 & 28 & 77,78 & & \\
\hline \multirow{2}{*}{ Item 4} & Agree & 12 & 28,57 & 4 & 13,79 & 5 & 13,89 & \multirow{2}{*}{3,507} & \multirow{2}{*}{0,173} \\
\hline & Not agree & 30 & 71,43 & 25 & 86,21 & 31 & 86,11 & & \\
\hline \multirow{2}{*}{ Item 5} & Agree & 6 & 13,04 & 0 & 0,00 & 4 & 11,11 & \multirow{2}{*}{4,110} & \multirow{2}{*}{0,128} \\
\hline & Not agree & 40 & 86,96 & 30 & 100,00 & 32 & 88,89 & & \\
\hline \multirow{2}{*}{ Item 6} & Agree & 8 & 17,39 & 5 & 16,67 & 6 & 15,79 & \multirow{2}{*}{0,038} & \multirow{2}{*}{0,981} \\
\hline & Not agree & 38 & 82,61 & 25 & 83,33 & 32 & 84,21 & & \\
\hline \multirow{2}{*}{ Item 7} & Agree & 13 & 33,33 & 15 & 53,57 & 22 & 61,11 & \multirow{2}{*}{6,172} & \multirow{2}{*}{$0,046^{*}$} \\
\hline & Not agree & 26 & 66,67 & 13 & 46,43 & 14 & 38,89 & & \\
\hline \multirow{2}{*}{ Item 8} & Agree & 21 & 56,76 & 19 & 76,00 & 25 & 71,43 & & \\
\hline & Not agree & 16 & 43,24 & 6 & 24,00 & 10 & 28,57 & 2,983 & 0,225 \\
\hline Item 9 & Agree & 27 & 72,97 & 17 & 70,83 & 25 & 75,76 & & 915 \\
\hline Item 9 & Not agree & 10 & 27,03 & 7 & 29,17 & 8 & 24,24 & $1 / 8$ & 0,915 \\
\hline Item 10 & Agree & 22 & 68,75 & 20 & 80,00 & 19 & 55,88 & & 0145 \\
\hline item 10 & Not agree & 10 & 31,25 & 5 & 20,00 & 15 & 44,12 & 3,858 & 0,145 \\
\hline Item 11 & Agree & 30 & 71,43 & 24 & 88,89 & 28 & 80,00 & & \\
\hline item 11 & Not agree & 12 & 28,57 & 3 & 11,11 & 7 & 20,00 & 046 & 18 \\
\hline & Agree & 16 & 41,03 & 10 & 45,45 & 16 & 47,06 & & \\
\hline Item 12 & Not agree & 23 & 58,97 & 12 & 54,55 & 18 & 52,94 & 286 & 67 \\
\hline Itom 13 & Agree & 14 & 32,56 & 8 & 33,33 & 9 & 25,71 & & \\
\hline Item 13 & Not agree & 29 & 67,44 & 16 & 66,67 & 26 & 74,29 & 556 & ot \\
\hline Item 14 & Agree & 2 & 4,65 & 6 & 20,69 & 5 & 13,51 & 4376 & 0112 \\
\hline Item 14 & Not agree & 41 & 95,35 & 23 & 79,31 & 32 & 86,49 & $4,3 / 0$ & 0,112 \\
\hline Item 15 & Agree & 3 & 6,38 & 3 & 10,34 & 3 & 8,33 & 0387 & 0824 \\
\hline item 15 & Not agree & 44 & 93,62 & 26 & 89,66 & 33 & 91,67 & $0,38 /$ & $0,8<4$ \\
\hline & Agree & 1 & 2,00 & 1 & 3,23 & 2 & 5,56 & 0806 & 0668 \\
\hline Item 16 & Not agree & 49 & 98,00 & 30 & 96,77 & 34 & 94,44 & 0,800 & 0,068 \\
\hline
\end{tabular}

In addition, Table 4 presents the results of the chi-square analysis to compare the views of the individuals according to their educational background. When the rates of participation in the proposition were statistically analysed, there was a significant difference between the answers given $(\mathrm{p}<0,05)$. It was determined that the participants who are undergraduate / graduate graduates were more likely to participate in this proposition than those who were graduated from primary / high school. According to the educational status of the participants, the difference between the responses to the other propositions was not statistically significant $(p>0.05)$. See Table 4. 
Table 4: Comparison of participants' views on the Nicosia Walled City region according to their educational background

\begin{tabular}{|c|c|c|c|c|c|c|c|}
\hline & & \multicolumn{2}{|c|}{$\begin{array}{l}\text { Primary / } \\
\text { Secondary }\end{array}$} & \multicolumn{2}{|c|}{$\begin{array}{c}\text { Undergraduate / } \\
\text { Graduate }\end{array}$} & \multirow[t]{2}{*}{$\mathbf{X}^{2}$} & \multirow{2}{*}{$\mathrm{p}$} \\
\hline & & $\mathbf{n}$ & $\%$ & $\mathrm{n}$ & $\%$ & & \\
\hline \multirow{2}{*}{ Item 1} & Agree & 29 & 65,91 & 28 & 48,28 & \multirow{2}{*}{3,155} & \multirow{2}{*}{0,076} \\
\hline & Not agree & 15 & 34,09 & 30 & 51,72 & & \\
\hline \multirow{2}{*}{ Item 2} & Agree & 17 & 41,46 & 11 & 22,45 & \multirow{2}{*}{3,766} & \multirow{2}{*}{0,052} \\
\hline & Not agree & 24 & 58,54 & 38 & 77,55 & & \\
\hline \multirow{2}{*}{ Item 3} & Agree & 11 & 22,92 & 5 & 7,94 & \multirow{2}{*}{4,956} & \multirow{2}{*}{$0,026^{*}$} \\
\hline & Not agree & 37 & 77,08 & 58 & 92,06 & & \\
\hline \multirow{2}{*}{ Item 4} & Agree & 11 & 23,40 & 10 & 16,67 & \multirow{2}{*}{0,758} & \multirow{2}{*}{0,384} \\
\hline & Not agree & 36 & 76,60 & 50 & 83,33 & & \\
\hline \multirow{2}{*}{ Item 5} & Agree & 5 & 9,80 & 5 & 8,20 & \multirow{2}{*}{0,088} & \multirow{2}{*}{0,766} \\
\hline & Not agree & 46 & 90,20 & 56 & 91,80 & & \\
\hline \multirow{2}{*}{ Item 6} & Agree & 9 & 18,37 & 10 & 15,38 & \multirow{2}{*}{0,179} & \multirow{2}{*}{0,672} \\
\hline & Not agree & 40 & 81,63 & 55 & 84,62 & & \\
\hline \multirow{2}{*}{ Item 7} & Agree & 21 & 46,67 & 29 & 50,00 & \multirow{2}{*}{0,113} & \multirow{2}{*}{0,737} \\
\hline & Not agree & 24 & 53,33 & 29 & 50,00 & & \\
\hline \multirow{2}{*}{ Item 8} & Agree & 31 & 68,89 & 34 & 65,38 & \multirow{2}{*}{0,134} & \multirow{2}{*}{0,714} \\
\hline & Not agree & 14 & 31,11 & 18 & 34,62 & & \\
\hline Item 0 & Agree & 30 & 71,43 & 39 & 75,00 & & \\
\hline Item 9 & Not agree & 12 & 28,57 & 13 & 25,00 & 0,152 & 0,091 \\
\hline Item 10 & Agree & 27 & 62,79 & 34 & 70,83 & 0664 & 0415 \\
\hline $1 \mathrm{cem} 10$ & Not agree & 16 & 37,21 & 14 & 29,17 & 0,004 & 0,415 \\
\hline Item 11 & Agree & 39 & 81,25 & 43 & 76,79 & 0300 & 0578 \\
\hline Item 11 & Not agree & 9 & 18,75 & 13 & 23,21 & 0,309 & $0,5 / 8$ \\
\hline & Agree & 17 & 40,48 & 25 & 47,17 & 0426 & \\
\hline Item 12 & Not agree & 25 & 59,52 & 28 & 52,83 & 0,426 & 0,514 \\
\hline Item 13 & Agree & 13 & 27,66 & 18 & 32,73 & 0308 & 0570 \\
\hline Item 13 & Not agree & 34 & 72,34 & 37 & 67,27 & 0,308 & $0,5 / 9$ \\
\hline Item 14 & Agree & 6 & 13,33 & 7 & 10,94 & 0144 & 0704 \\
\hline Item 14 & Not agree & 39 & 86,67 & 57 & 89,06 & 0,144 & $0, / 04$ \\
\hline & Agree & 5 & 11,11 & 4 & 5,97 & 0963 & \\
\hline Item 15 & Not agree & 40 & 88,89 & 63 & 94,03 & 0,963 & 0,326 \\
\hline Item 16 & Agree & 3 & 6,12 & 1 & 1,47 & & \\
\hline Item 16 & Not agree & 46 & 93,88 & 67 & 98,53 & 1,860 & $0,1 / 2$ \\
\hline
\end{tabular}

\subsubsection{Evaluation of the Findings}

As it is seen in the results of the survey, the users prefer the Arasta, Büyükhan and Selimiye regions which are recently restorated, rehabilitated and re-functionalized in terms of urban design. On the other hand, it is observed that Abdi Çavuş Street and Yeni Cami region having a low economic and socio-cultural structure are not preferred and have negative effects on the users, due to the lack of maintenance and urban design implementations.

In addition, according to the findings of the survey conducted in Nicosia Walled City, 
the opinions of the users about these implementations were mostly negative. The users find the green areas and pedestrian roads insufficient and they think that the existing urban furniture elements are not sufficient. They have further suggested that the biggest problem in the region is the lack of parking lots and environmental pollution. But they also argued that they were satisfied with the traffic and public transportation to the region was necessary. They also tend to agree with the suitability of the facade and floor coverings used in the renovation works in the region to the historical environments. And they also tend to agree that restoration and re-functionalization in the region contributes to the regional economy. They further think that the pedestrianization activities in certain regions contribute to the economy of Walled City in particular. And they believe that the historical environment in the region should be protected. But it can also be argued that the users who participated in the survey are not sufficient for the existing rehabilitation and restoration works in Walled City.

Also, according to the results of the research, 96.88\% of the participants tend to find it convenient that the re-functioned structures in the region are used by universities, artists or non-governmental organizations and at the same time, $94,29 \%$ of participants tend to find it convenient that these structures are used by restaurants with bars, cafes and the like for city users. It was determined that it was found appropriate. For this reason, we can suggest that the restoration, rehabilitation and re-functionalization activities have made the region more preferred to visit.

In other words, due to the fact that it achieves a rich urban identity, it attracts the attention of many organizations and is still preferred by investors. Nicosia has become more attractive for new investments due to the positive impact of these urban design works. Conservation, adaptive reuse, rehabilitation and re-functionalization activities in this region have enabled the region to be preferred by the users. However, it can further suggested that these restorations and re-functionalized spaces are being implemented in certain parts of Walled City.

\section{Conclusion and Discussion}

Sustainable urban planning and design has been acknowledged as a key concept as we are facing disparate challenges in day by day enlarging cities (Oktay, 2012; Sharifi, 2016). Cultural sustainability is one of the main dimensions of the sustainable urbanism and historic quarters, monuments, buildings as cultural heritage entities have a prominent place for boosting the cultural sustainability. Such historic buildings, archaeological sites, monuments are classified as immovable heritage as one of the sort of tangible cultural heritage.

However rapid urbanization are damaging the historical environments. Therefore, especially after the Second World War, protection of historic entities via conservation, rehabilitation, renovation, restoration, regeneration, adaptive reuse etc. gained momentum. In order to ensure sustainability in historical environments, it is necessary to regulate the social, economic and cultural structure and to protect it as a whole with contemporary architecture and technological improvements in a more holistic perspective.

For this purpose, in addition to providing financial resources and necessary technology, 
technical infrastructure etc. for conservation and restoration activities in historical environments, it should be targeted to raise awareness and inclusion of the residents. Such an attempt would achieve the accomplishment of these urban design activities. Raising awareness and concern of the community about the significance of historic environments and the efforts to make the individuals prefer and use these environments for different purposes can be via disparate methods including education etc.

But it is for sure that urban design activities involving such as conservation, regeneration, rehabilitation, revitalization, adaptive reuse, restoration is a very effective tool to make the historic environments more qualified, liveable and sustainable and these efforts have the ability to connect our past to the future.

\section{References}

Ahunbay, Z. (1996). Taribi Cevre Koruma ve Restorasyon. İstanbul: Yap1 Endüstri Merkezi, 116-135.

Alpopi, C., \& Manole, C. (2013). Integrated Urban Regeneration - Solution for Cities Revitalize. Procedia Economics and Finance, 178-185.

Altan, Z. (2016). Gižemli Kıbrıs. Lefkoşa: Okman Printing, 307-385.

Bolkaner, M. K., İnançoğlu S., \& Asilsoy B. (2019). A Study on Urban Furniture: Nicosia Old City, European Journal of Sustainable Development, 8, 2, pp: 1-20, ISSN: 2239-5938.

Cavdar, Ü., \& Sayan, M. (2003). Tarihi Kent Dokularında Dönüşüm ve Süreklilik; Antalya Kale İçi Örneği. Uluslararası 14. Kentsel Tasarm ve Uygulamalar. Antalya: Akdeniz Üniversitesi Ziraat Fakültesi Peyzaj Mimarlığı.

Çelik, D. (2004). Doktora Tezi. Kentsel Peyzaj Tasarm Kapsammnda Taribi Cevre Yenileme Caahsmalarmm Peyzaj Mimarluğ Aģısından Araștırlması: Beypazar Örneği, 219. Ankara, Türkiye: Ankara Üniversitesi Fen Bilimleri Enstitüsü Peyzaj Mimarlı̆̆ Ana Bilim Dalı.

Çelik, D., \& Yazgan, M. (2007). Kentsel Peyzaj Tasarımı Kapsamında Tarihi Çevre Korumaya Yönelik Yasa ve Yönetmeliklerin İncelenmesi. ZKÜ Bartm Orman Fakültesi Dergisi, 9(11), 10.

Davies, L. (2000). Urban Design Compendium. 1. The Housing Coorporation. London.

Dincyurek, O., \& Turker, O. O. (2007). Learning from traditional built environment of Cyprus: Reinterpretation of the contextual values. Building and Environmet. 42, 3384-3392

Doratli, N., Hoşkara, S., \& Fasl1, M. (2004). An Analitical Methodology For Revitilazition Strategies In Hstoric Urban Quarters: A Case Study Of The Walled City Of North Cyprus. Cities. 21(4), 329-348.

Fielden, B. (1982). Conservation Of Historic Buildings. London: Butter Worth And Co.

Governo Do Brasil. (2010). Caminho Dos Antiqarios. Ocak 2018 tarihinde Governo Do Brasil:http://www.brasil.gov.br/esporte/especial-copa-do-mundo/copadomundo/brasil2014/imagens/cidades/porto-alegre/caminho-dos-antiquarios/view adresinden alınd1

Gürkan, H. (1996). Dünkü ve Bügünkü Lefkoşa Toplu Eserler 3. Lefkoşa: Galeri Kültür Yayınlar1, 11-85.

Hasol, D. (1998). Ansiklopedik Mimarlk Söəlïgüü. İstanbul: Yapı EndüstriMerkez Yayınları, s.274.

Hoşkara, Ş. (2008). Kentsel Tasarım Kuramı, Dün, Bügün, Yarın ve İstanbul Yansımaları. Mimarist Dergisi (29), 31-33.

Hürriyet. (2017). Hürriyet Haber. İtalyada Ortaçă̆ Şehri: Siena. Mart 2018 tarihinde http://www.hurriyet.com.tr/seyahat/italyada-ortacag-sehri-siena-40617384 adresinden alındı

Kamruzzaman M., Deilami K., Yigitcanlar T. (2018). Investigating the urban heat island effect of transitoriented development in Brisbane Journal of Transport Geography, 66, pp. 116-124.

Karaman, A. (2008). Kentsel Tasarım: Kuramlar, İlkeler, Roller. Mimarist Dergisi(29), 34-42.

Kibris.com.tr. (2018). Kuzey Kıbris Haritalar, Kıbrıs Karayollarn Haritası 2018 tarihinde Kibris.com.tr: https://kibris.com.tr/images/haritalar/kibris_karayollari_haritasi.jpg adresinden alınd1

Kuban, D. (2000). Taribi Çevre Koruman Mimarlke Boyutu Kuram ve Uygulama, 207. İstanbul: Yap1 Endüstri Merkez Yayınları.

Lynch, K. (1960). The Image Of The City. Mussachusetts: The Mit Press. 
Marquez-Ballesteros M-J., Mora-López L., Lloret-Gallego P., Sumper A., Sidrach-de-Cardona M. (2019). Measuring urban energy sustainability and its application to two Spanish cities: Malaga and Barcelona, Sustainable Cities and Society, Vol 45, pp. 335-347.

Moughtin, C. (2003). Urban Design:Street And Square. Oxford: Architectural Press.

Oktay, D., \& Hoşkara, Ş. (2006). Tarihi Kentsel Alanların Korunmasında Sürdürülebilir Canlandırma Yaklaşımı. Yapı Dergisi(296), 38-42.

Oktay, D (2012). Human sustainable urbanism: In pursuit of ecological and social-cultural sustainability. Procedia-Social and Behavioral Sciences, 36, 16-27.

Project For Public Spaces. (2016). Project For Public Spaces. Mart 2018 tarihinde Piazza Del Campo , Siena Italy: https://www.pps.org/places/piazza-del-campo adresinden alındı

Roberts, P., \& Sykes, H. (2000). The Evolotion,Definition and Purpose of Urban Regeneretion. A Handbook. Sage.

Sharifi, A. (2016). From garden city to eco-urbanism: The quest for sustainable neighborhood development. Sustainable Cities and Society, 20, 1-16

T.R.N.C. City Planning Department. (2018). Birds- eye view of Nicosia. March 2018 http://spd.gov.ct.tr/trtr $/ \%$ C $3 \%$ BCstmenu/anasayfa.aspx

Tunçer, M. (1997). Çevre Planlama ve Tasarıma Bütüncül Yaklaşım Sempozyumu, Çevre Planlama ve Tasarım Haftası 96 Etkinlikleri. Doğal Cevre ve Kültürel Cevrenin Bütüncül Planlanmasi: Antalya Örneği. Ankara: Ankara Üniversitesi Peyzaj Mimarlı̆̆ı Bölümü.

Turkan, Z., \& Özburak, Ç. (2018). Lefkoşa Tarihi Kent Dokusunda "Selimiye Meydanı" ("Selimiye Square” within the Historical City Texture of Nicosia). Journal of History Culture and Art Research, 7 (2), 430443.

Uğur, H., \& Giritlioğlu, C. (2006). Geleneksel Şehirsel Dokular ve Kullanıcı Özellikleri. İTÜ Dergisi, 5(1), 2934.

Vehbi, O., \& Hoşkara, Ö. (2009). Model For Measuring The Sustainability Level Of Hictoric Urdan Quarters. European Planing Studies. 17(5), 715-739.

Wang, J. (2012). Problems and solutions in the protection of historical urban areas. Frontiers of Arcbitectural Research, 1, 40-43.

Yazgan, M., \& Erdoğan, E. (1992). Taribi Cevrelerde Peyzaj Planlama. (2), 87. Ankara: Ankara Üniversitesi Ziraat Fakültesi Peyzaj Mimarlığı Bölümü Peyzaj Mimarisi Derneği Yayınları. 